\title{
リン脂質と中性脂質の相互作用と構造形成について
}

\author{
半 田 哲 郎
}

京都大学薬学部 荬606-01 京都市左京区吉田下阿達町

\section{Structure-Organization of Phospholipid-Neutrallipid Mixtures in Aqueous Phase}

\section{Tetsurou Handa}

Faculty of Pharmaceutical Sciences, Kyoto University, Sakyo-ku, Kyoto, 606-01 Japan

Interfacial equilibria among various liquid-crystalline structures of lipid and lipid mixtures are reviewed and the physiological relevance of the equillibria is discussed. Phospholipid-neutrallipid mixtures form various liquidcrystalline structures, including bilayers, micelles, emulsions, reverse hexagonal and reverse cubic structures. Neutral lipids, such as triglycerides, cholesterylesters and ubiquinone-10 have very limited solubillties in bilayers of phosphatidylcholine (PC). Excess amount of neutral lipid is separated from the bilayers and forms the droplets in an aqueous medium. The droplets are covered by the PC monolayers spread from the bilayers, and are stabilized as emulsion particles. Lipoproteins, chylomicrons and very low density lipoproteins, in animal plasma are such particles containing a very small amount of several different apoproteins. The lipid composition of emulsions influences the affinity to apoproteins in plasma, and controls the catabolism of the particles in vivo.

Some other neutral lipids, such as diglycerides, monoglycerides, $\alpha$-tocopherol and menaquinone-4 have large solubilities in the PC bilayers. Addition of such a neutral lipid to the bilayers occasionally induces formation of irregular structures (intrabilayer-particles or -micelles) and vesiculation of the bilayers. The intrabilayer-structures are considered to be precursors for reverse hexagonal and reverse cubic structures. Diglycerides and $\alpha$-tocopherol in the PC bilayers activate phospholipases $\mathrm{A}_{2}, \mathrm{C}$ and D.

Key Words : structure-organization, phospholipid-neutrallipid mixtures, bilayers, lmulsions, lipoproteins, reverse hexagonal structure, reverse cubic structure.

\section{1. はじめに}

動物体内の脂質分子集合体の構造として，細胞膜など の 2 分子膜 (bilayers) がよく知られている.しかし, 肺胞表面で bilayers と動的平衡を保ちながら呼吸機能 に関与しているのはリン脂質 (PL) の単分子膜 (mono- layers) である1). 血液中で高カロリ一源のトリグリセ ライド $(\mathrm{TG})$ やコレステリルエステル $(\mathrm{CE})$ を運搬す るリポ蛋白, chylomicrons (CM), very low density lipoproteins (VLDL) や low density lioproteins (LD L) は中性脂質 ( TG, CE) の液摘が表面の PL 単分子膜 により水中に安定化されたエマルション (emulsions) 
<smiles></smiles>

Phosphatidylcholine (PC)

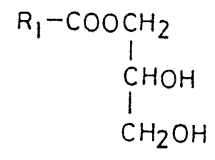

$M \quad G$

$$
\begin{gathered}
\mathrm{R}_{1}-\mathrm{COOCH}_{2} \\
\mathrm{CH}_{2}-\mathrm{COOCH} \\
1 \\
\mathrm{CH}_{2} \mathrm{OH}
\end{gathered}
$$

D G<smiles>[R]OC(=O)OCC(COC([R])=O)C(=O)O[2H]</smiles>

$T G$

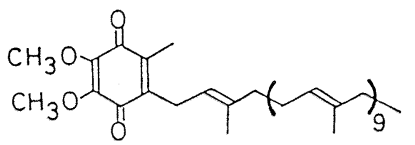

Ubiquinone-10 ( Q10)
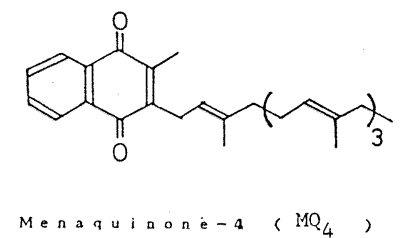

Fig. 1. レシチン $(\mathrm{PC})$ と中性脂質

である. また，ミセル (micelles) 様の high density lipoproteins (HDL) も知られている. 血液中のこれら の脂質分子集合体の間の脂質の移動は代謝エネルギーを 必要とせず, 脂質分子の物理化学的ポテンシャルによっ て支配されている1)。医療用に実用化されている脂肪乳 剤はレシチン $(\mathrm{PC}) /$ /トグリセライド $(\mathrm{TG})$ エマル ションであり, $\mathrm{CM}$ とほぼ同じ異化を体内でうける2).

一方, PC 2 分子膜にジグリセライド (DG) が添加さ れるとその構造か活れ, ついには逆へキサゴナル構造 $\left(\mathrm{H}_{\mathbb{1}}\right)$ を生成する， $\mathrm{H}_{\mathbb{1}}$, あるいは, そのプリカーサーは 2 分 子膜の融合や各種 phospholipase の活性化を誘導し, 膜における情報伝達メカニズムに関係すると考えられて いる ${ }^{3)}$.

このように, 体内で種々の脂質分子集合体の重要な働 きが明らかになりつつある.しかし,これらの間の平衡, 脂質分子の交換などの生物物理学的研究は少ない，本稿

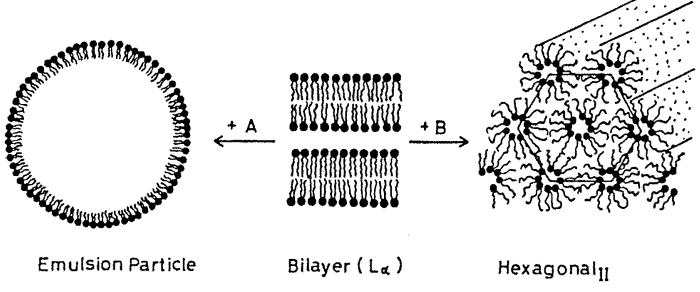

Fig. 2. 中性脂質 (A あるいは B) 添加による 2 分 子膜構造変化

$\mathrm{A}: \mathrm{TG}, \mathrm{CE}, \mathrm{Q}_{10}, \mathrm{VEA}$ など, $\mathrm{B}: \mathrm{DG}$, $\mathrm{VE}, \mathrm{MG}, \mathrm{MQ}_{4}$ なよ゙

では，おもに界面化学的手段による筆者らの研究例を紹 介する。

\section{2. エマルションかヘキサゴナルாか}

レシチン (PC) 2 分子膜に中性脂質が添加されても全 ての場合にエマルションが形成されるわけでない. Fig. 1 に示すような $\mathrm{TG}, \mathrm{CE}$, ユギキノン- $10\left(\mathrm{Q}_{10}\right)$ あるいは ビタミンEアセテート (VEA) などは $\mathrm{PC}$ と水中に共分 散されれば, 安定な乳化分散粒子 (Fig. 2 参照) を生 成する1). chylomicrons や VLDL は TG や CE が PCによって安定化された乳化粒子（エマルション）で ある11。

一方, DG やビタミン E (VE) は PC と共には乳化粒 子 (エマルション) を形成しない. 2 分子膜は DG 添加

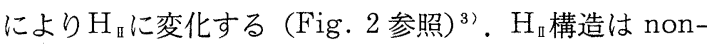
bilayer 構造の 1 つである. $\mathrm{H}_{\mathbb{1}}$ を $\mathrm{PC}$ の 2 分子膜に誘導 する DG は細胞内の情報伝達物質として注目されてい る. 筆者等は, DG が PC 2 分子膜に対する phospholipase D の活性を增大させることを見出した ${ }^{4)}$ 。また， モノグリセライド (MG) は PC 2 分子膜を bicontinuous cubic phaseへと変化させる ${ }^{5)}$.このcubic phase も $\mathrm{H}_{\text {匹 }}$ 同様に逆トポロジーの non-bilayer 構造の 1 つ である.

\section{3. エマルションと 2 分子膜の平衡と共存}

PC が水中に安定に形成する構造は 2 分子膜 (bilayers)，あるいは，これが層状に積み重なったラメラ 一相 (lamellar phase) である. liposomes（リポソー ム）は単一あるいは複数の 2 分子膜が，球状または同心 球状に閉鎖した小胞 (vesicles) である.この 2 分子膜 


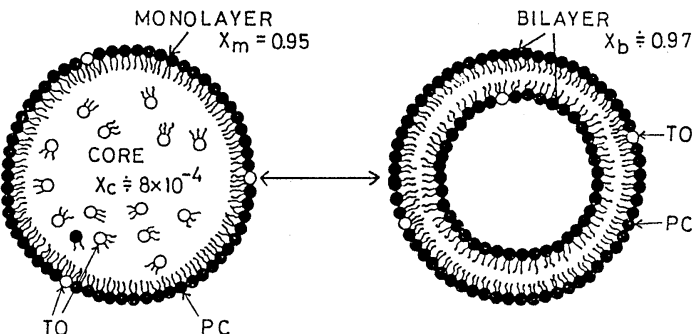

EMULSION PARTICLE

Fig. 3. エマルションとリポソームの平衡と共存. (TGとしては triolein を用いた. 本文参照)

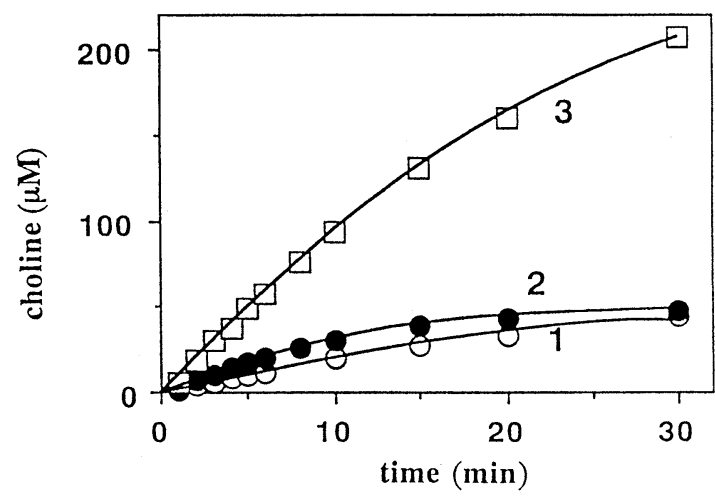

Fig. 5. phospholipase D による PC 2 分子膜の 加水分解

1: $\mathrm{PC}$ のみ, $2: \mathrm{PC}+18$ モル\%コレステ ロール, $3: \mathrm{PC}+18$ モル\%ジグリセライド

に中性脂質が添加されるとよ゙のような構造変化が起こる だろう。

$\mathrm{TG}, \mathrm{CE}, \mathrm{Q}_{10}$ や VEA などは PC 2 分子膜への溶解 度が小さい，溶解度以上に添加された過唾の中性脂質は 2 分子膜から分離し, 水中に中性脂質の液滴を形成する. 油滴之水の界面張力（界面エネルギー）は大きい. 2 分 子膜の PC が一部この界面に移動（拡張, spreading） し単分子膜 (monolayers) を形成すると, そのエネル ギーは低下して油滴は安定化される ${ }^{1)}$ 。このようにして 得られる中性脂質と PC による安定なエマルション分散 系には，エマルション粒子と 2 分子膜（すなわち，リポ ソーム粒子）が共存する.このことは実用化されている $\mathrm{TG} / \mathrm{PC}$-脂肪乳剂 (Intralipid) において広く実証され ている ${ }^{6)}$. また $\mathrm{PC} / \mathrm{TG}$ エマルションやこれを基本構 造とする $\mathrm{CM}$ や VLDL の体内異化において, エマル ション表面単分子膜と 2 分子膜の動的平衡関係は重要で ある ${ }^{7)}$.

Fig. 3 に TG／PC エマルション粒子と PC リポソー

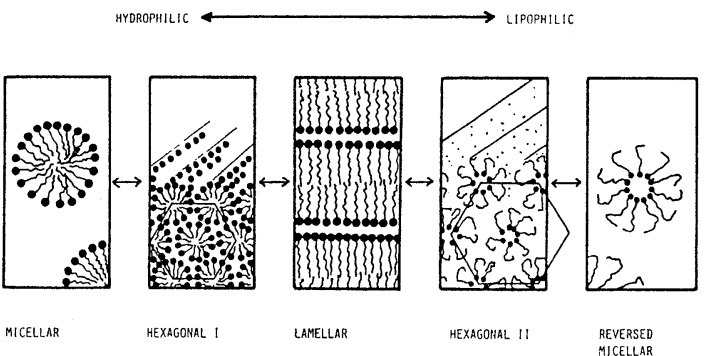

Fig. 4. 脂質あるいは脂質混合物の親水性一親油 性バランスと水中に形成される液晶構造

ムの共存を示した. リポソーム 2 分子膜とエマルション 単分子膜中に溶解している TG 量は, それぞれ，3およ び 5 モル\%である．筆者等は，人工のエマルションのみ ならず, CM やVLDM でも粒子表面の TG 濃度が一定 に保たれるのは, この 2 分子膜と表面単分子膜の(動的) 平衡によることを示した ${ }^{8)}$.

$\mathrm{TG} / \mathrm{PC}$ エマルションを動物体内（血漿）に投与す ると，血管表皮細胞での TG の消化吸収 (lipolysis) と 残存粒子の肝細胞による取り込みの 2 つの過程により異 化される. lipolysis により emulsion 内部の TG が減 少して過剰の表面膜が 2 分子膜として析出するが, 血漿 中のアポリポ蛋白 A-1の作用によりミセル化 ( $\mathrm{HDL}$ 化）する ${ }^{9)}$. また，エマルションにコレステロールやそ のエステルを添加すると 2 つ過程に大きな影響を与え $る^{10)}$.これらの結果は天然のリポ蛋白 CM や VLDL に も見い出される現象と密接な関係があり, 高脂血症の研 究や薬物送達システムへの人工のエマルションの利用に 大きな期待がもたれている.

\section{4. ジグリセライドとモノグリセライド}

ジグリセライド (DG) とモノグリセライド (MG) は PC 2 分子膜にかなりよく溶ける. 相当量の $D G$ や $M G$ が添加されても 2 分子膜からの分離は起こらない. Fig. 4 に示されるように，脂質あるいは脂質混合物が水中に 形成する液晶の構造は, その親水性一親油性バランスに よって決定される" . バランスのとれた PC は 2 分子膜 やこれがつみかさなった lamellar 相を形成する，PC より脂肪酸を 1 分子除いた lyso-PC は親水性が高くミ セルを形成する. また PC 2 分子膜に TG を加えても， その溶解度は 3 モル\%で低く, 2 分子膜構造は維持され る. 前述したように過剰の TG はエマルションの内部 液滴を形成する. 

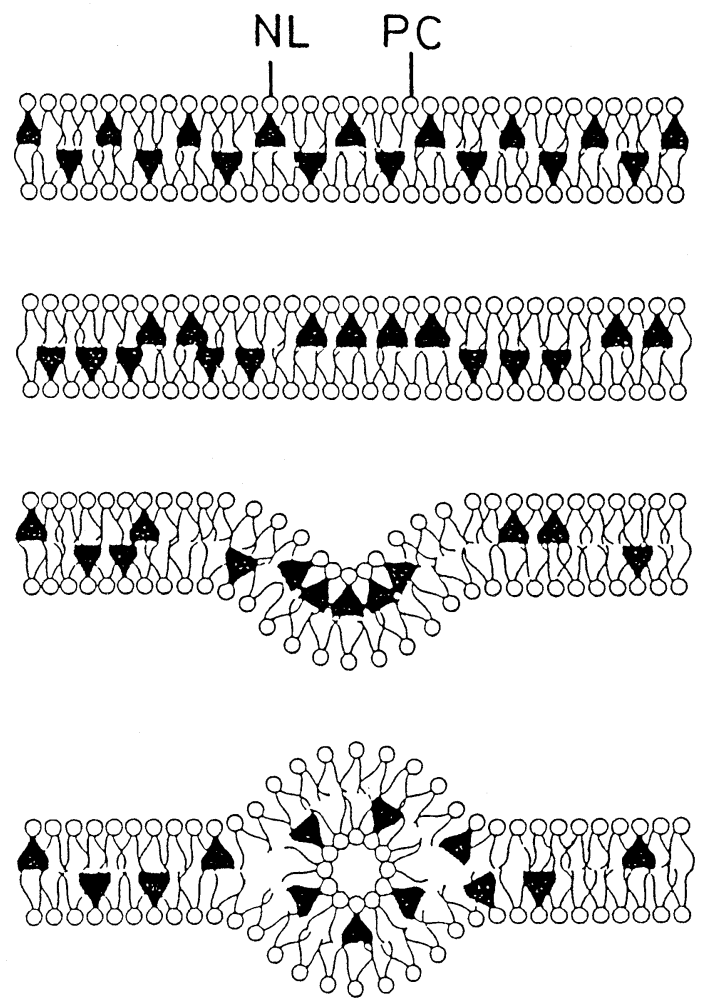

Fig. 6. レシチン (PC) 2 分子膜に中性脂質 (NL) が添加されたときの構造変化 $\mathrm{NL}$ : 図 2 のB型脂質

一方, DG は PC2分子膜によく溶け, その親油性を 高める. $30 \%$ 以上添加されると 2 分子膜は逆へキサゴ ナル $\left(\mathrm{H}_{\mathrm{II}}\right)$ 構造に変化する ${ }^{3)}$. 親油基が外側に向いた 逆卜ポロジーをもつ $\mathrm{H}_{\text {几 }}$ はその疎水性のため水中に安定 に分散しにくい. 2 分子膜から $\mathrm{H}_{\text {匹 }}$ 変化する途中で多様 な構造の乱れや変化が存在することが指摘されている が，その詳細ははっきりしていない，筆者等は PC 2 分 子膜に対するホスフォリパーゼ D (PLD) の活性が TG の添加により著しく増加することを見出した. コレステ ロールの添加はPLD の活性にほとんど影響しない4 (Fig. 5 参照). PLD の活性化は膜による情報伝達機能 と関係し大きな注目をあびている. PLDの活性化は, 2 分子膜中の基質 $\mathrm{PC}$ のリン酸基周辺の運動性がDG の添 加により増大することと関係している.

モノグリセライド MG も DG と同様に PC 2 分子膜 によく溶ける. MGの添加は2 分子膜を親油性に傾け, 逆トポロジーの cubic phase を生成させる5 . この構 造は Fig. 4 の 2 分子膜 (lamellar) とHッ構造の中間に

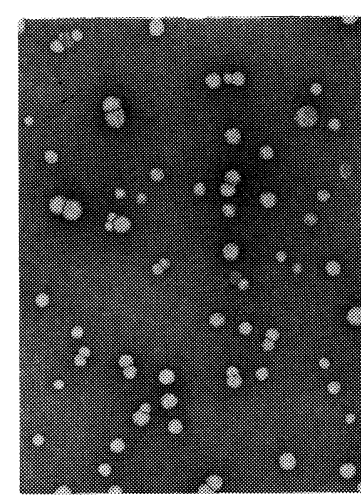

(a)

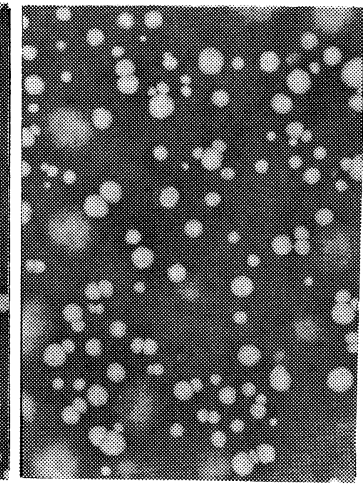

(b)

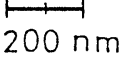

Fig. 7. $\mathrm{Q}_{10}-\mathrm{PC}$ 混合物の水中分散粒子 (a) $\mathrm{Q}_{10} / \mathrm{PC}=5 / 5$, 平均粒径 $65 \mathrm{~nm}$ (b) $\mathrm{Q}_{10} / \mathrm{PC}=7 / 3$, 平均粒径 $75 \mathrm{~nm}$

位置する。親油基が外側に向いた逆トポロジーをもつこ れらの構造は生物物理学的にも重要であるが, その研究 はあまり進展していない. MG が PC 2 分子膜に添加さ れると, マルチラメラリポソームから微小リポソームの 変化がおこりやすくなる11)。同様のことはレチノール (ビタミンA)-レシチン系でも見出せる. Fig. 6 に示す ように疎水性(親油性) の高い $M G$ が非対称的に 2 分子 膜の表裏に分布すれば, 膜のヴェジクル化がおこりやす くなる，微小ヴェジクル (SUV) 表裏での中性脂質の非 対称性は $\alpha$-tocopherol (VE) 含有系で知られている ${ }^{12)}$.

\section{5. レシチンとユビキノン 10 による エマルション形成}

ユビキノン $10\left(\mathrm{Q}_{10}\right)$ は動物細胞のミトコンドリアの エネルギー代謝, 酸化的リン酸化の電子伝達にも不可欠 の中性脂質であり, 種々の機能向上や回復にも有効であ る. $\mathrm{Q}_{10}$ 亡 PC の単分子膜-2 分子膜平衡, DSC や NMR なよ゙の測定により, PC 2 分子膜には $Q_{10}$ は $5 \%$ しか溶 解しないことがわかった，過剒の $\mathrm{Q}_{10}$ は, TGの場合同 様に, 分離して水中に油滴を形成する. 油滴は PC 単分 子膜に覆われ, エマルション粒子として安定化される. この安定なエマルション粒子は PCの 2 分子膜（すなわ ち, liposomes）上共存する ${ }^{13)}$. (室温付近では $Q_{10}$ は 固体であり，エマルション粒子よりもむしろサスペン ション粒子と呼んだ方がよいかもしれない)。 


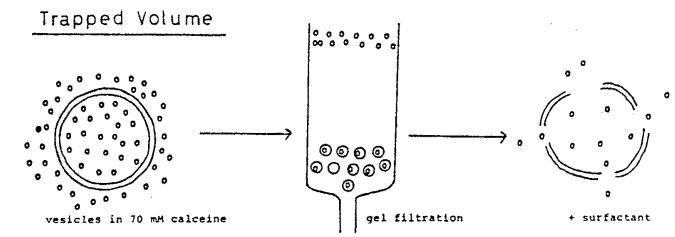

$-\mathrm{N}\left(\mathrm{CH}_{3}\right)_{3}{ }^{\prime} \mathrm{H}$-NMRChemical Shifts

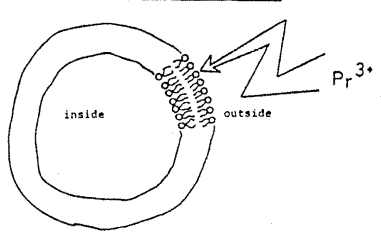

Fig. 8. エマルション粒子とリポソーム粒子を区 別する

Fig. 7 は $\mathrm{PC} / \mathrm{Q}_{10}$ がモル比で $5 / 5$ および $3 / 7$ で調 製された粒子の陰染色電顕写真である。 それぞれ，平均 粒径が 65 と $75 \mathrm{~mm}$ の安定な微粒子が形成される. Freeze-fracture 電顕で観察すると, 内部に $Q_{10}$ のコ アを持つサスペンション粒子と中空のリポソーム粒子の 混合物であることがわかった.

Fig. 8 にエマルション構造と 2 分子膜リポソーム構 造の判別法を示した. $70 \mathrm{mM}$ の蛍光色素カルセイン水 溶液で PC リポソーム (vesicles) を調製すると色素は リポソーム内水相に取り込まれる。ゲルろ過法によりリ ポソームと溶液中の色素は分離される。次に界面活性剂 を用いてリポソームを破壊すれば，内水相の色素は外に もれ希勫される. $70 \mathrm{mM}$ ではカルセインは自己消光の ためにほとんど蛍光を発光しないが，希釈されると強い 蛍光を放出する。これを利用してリポソームに trapd れた水相の体積を評価することができる，PC 1 モル当 りのリポソームが内部に取り込む水相の体積は small unilamellar vesicles (SUV) では 0.4 0.5 てである. $\mathrm{Q}_{10}$ が粒子内をうめ, エマルション粒子が増大すると卜 ラップ体積は小さくなる.

他方，水溶液中でリポソームを形成し，次に外側より 常磁性イオン $\left(\mathrm{Pr}^{3+}\right.$ など) を加えると, このイオンは 2 分子膜を透過できないので, 外側の PC とのみ相互作 用する. $\mathrm{Pr}^{3+}$ は NMR の化学シフトを变化させ, 内側 と外側の PC が別々に測定できるようになる. 内水相の ないエマルション構造の粒子が中性脂質 $\mathrm{Q}_{10}$ の添加に よりふえると, 内側に存在する PC 分子の割合が低下す る.この結果に基づいて(エマルション)/(リポソーム) の值を求めると $\mathrm{PC} / \mathrm{Q}_{10}=5 / 5$ ではほぼ 1 となる.
この值は trap 率から得られる值と一致する ${ }^{13)}$ 。この ように $\mathrm{PC} / \mathrm{Q}_{10}$ 系は $\mathrm{PC} / \mathrm{TG}$ 系とよく似た挙動を示 す。同様のことは $\mathrm{PC} /$ タミン $\mathrm{A}$ エステル，あるい は， PC／ビタミン Eエステル系などにも見い出される. $\mathrm{PC} / \mathrm{Q}_{10}$ エマルション粒子を動物体内に投与（血漿 中への投与) すると, $\mathrm{PC} / \mathrm{TG}$ や $\mathrm{PC} / \mathrm{CE}$ 系之同様に 肝細胞によく取り込まれる。しかし， $Q_{10}$ は他に心臟に も強い親和性を持つ事が知られている ${ }^{14)}$ 。この親和性 は, 血漿中の $Q_{10}$ 結合蛋白が $Q_{10}$ をエマルション粒子 より抜きとって心臟に送達する為か， $Q_{10}$ 含有粒子自身 が心臓細胞に親和性をもっているためか明らかではな い. 筆者等の最近の研究結果では後者であることが示唆 されている. 表面にわずかに露出している $Q_{10}$ により TGや $\mathrm{CE}$ とは異なる血漿蛋白選択性をエマルションが もつのであ万う。なお， $\mathrm{Q}_{10}$ は体内（血漿中）では $\mathrm{CM}$ やVLDLなどのリポ蛋白粒子に運ばれて移動してい る.

\section{6. メナキノン 4 によるレシチン 2 分子膜の 構造変化}

メナキノン 4 (menaquinone- $4, \mathrm{MQ}_{4}$, 別名ビタミン $\mathrm{K}_{2}$ ）は血友病などの治療効果をもつ有用な中性脂質で ある. $\mathrm{MQ}_{4}$ と $\mathrm{PC}$ 混合系の単分子膜之 2 分子膜平衡の 測定から, PC 2 分子膜には $\mathrm{MQ}_{4}$ は約 $20 \%$ 程度まで溶 解することがわかった ${ }^{15)}$. したがって, $\mathrm{PC} と \mathrm{MQ}_{4} の$ 混合物を水中で分散してもエマルション粒子は生成しに くい. 実際, 分散された $\mathrm{PC} / \mathrm{MQ}_{4}$ 粒子は内水相を持つ リポソームになりやすい，20 モル\%以上の過剩の $\mathrm{MQ}_{4}$ は2 分子膜より分離するが, これには PC が約 10 モル \%取り込まれており逆ミセル構造 (Fig. 4 参照) を形 成する. X 線小角散乱測定により, この逆ミセルが密に 充填した cubic 相の形成が示唆されている ${ }^{14)}$.

さて, $\mathrm{PC} 2$ 分子膜に $20 \%$ もの中性脂質 $\mathrm{MQ}_{4}$ が取り 込まれると, 膜の親水性一親油性バランスは後者に傾き, Fig. 9 や Fig. 10 で見られる irregular な構造が生成 される. $\mathrm{PC} / \mathrm{MQ}_{4}=2 / 8$ のultilamellar リポソー ムの 2 分子膜中に, 直径が約 $25 \mathrm{~nm}$ のミセル状の intrabilayer particles が観察される (Fig. 9). PCのみのリ ポソームではこのような構造は見つけられない. 同じ サンプル中の別の粒子に焦点をあわせると，200２50 $\mathrm{nm}$ のリポソーム内に約 $20 \mathrm{~nm}$ の SUV が点在するの が見られる (Fig. 10) ${ }^{15)}$. Fig. 10 の SUV は Fig. 9 の 


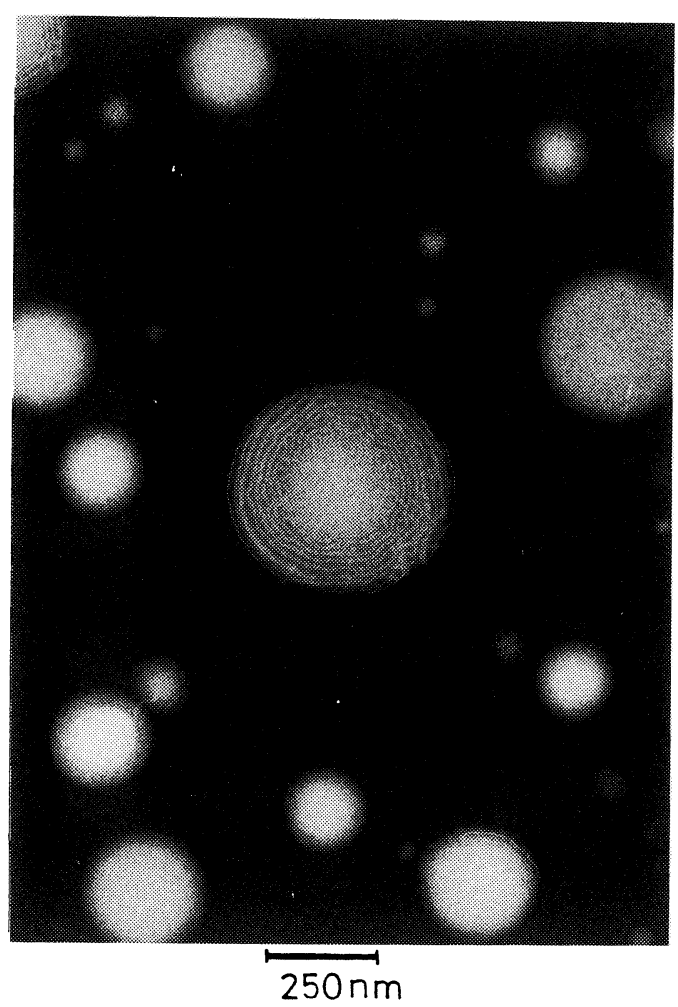

Fig. 9. $M Q_{4}-P C$ 混合物リポソームの不規則構造 1 $\mathrm{MQ}_{4} / \mathrm{PC}=8 / 2$, 内部の 2 分子膜に intrabilager particles が観察される.

intrabilayer particles が前駆体となって生成したもの と考えられる. 中性脂質による 2 分子膜の irregular 構 造形成は Fig. 6 で説明される. PC の分子は親水性一親 油性バランスがとれており,水中に 2 分子膜を形成する. 親油性が高く 2 分子膜への溶解性が大きい中性脂質が添 加されると, 膜は弯曲し, その凹面に濃縮されやすい. これが進むと, Fig. 9 のような intrabilayer particles が形成される.この粒子の内部構造, すなわち逆ミセル が密に充填すれば逆へキサゴナル相（棒状逆ミセル集合 体, $\mathrm{H}_{\mathbb{1}}$ ), あるいは逆キュビック相（球状逆ミセル集合 体）が生成する．また，この particles がバラバラに切 り離されると, Fig. 10 ような小ベシクル化 (2 分子膜 の fragmentation) がおこる1).

同様な小ベシクル化はモノグリセライド $(M G)$ やレ チノールによっても誘導されることは前述した.

\section{7. 結 論}

a. レシチンあるいはレシチンとコレステロール 2 分

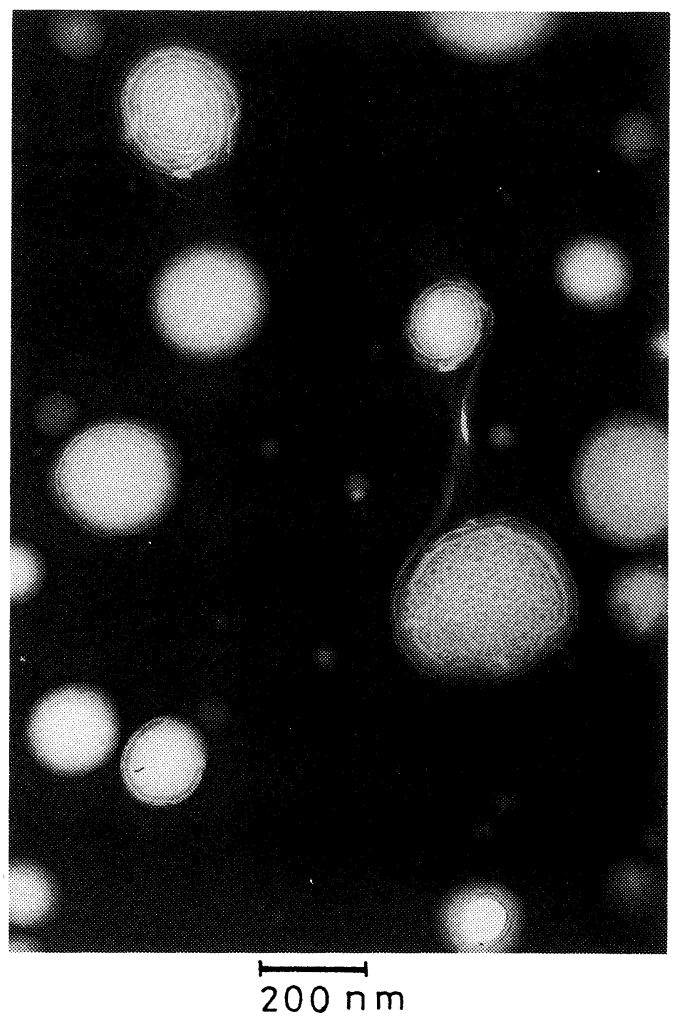

Fig. 10. $\mathrm{MQ}_{4}-\mathrm{PC}$ 混合物リポソームの不規則構 造 2

$\mathrm{MQ}_{4} / \mathrm{PC}=8 / 2$, 内部の多重 2 分子膜は フラグメント化し, 多数の SUV が観察 される.

子膜にトリグリセライド，またはコレステリルエステル を添加するとエマルション粒子が生成する.エマルショ ン粒子は 2 分子膜のリポソーム粒子と共存する。これら のエマルション粒子は動物血漿中のリポ蛋白モデルと見 ることができる. エマルション中のコレステロールやそ のエステル含量により，血管表皮細胞でのトリグリセラ イドの消化吸収, 肝細胞による粒子取り込みが大きく影 響される。

b. ユビキノン $10, \alpha$-トコフェロールエステルやレチ ノールエステルも同様にレシチンとエマルション構造を 形成する、ユビキノン 10 含有エマルションは動物体内 で特異的な挙動を示す。

c. ジグリセライド, メナキノン 4 や $\alpha$-トコフェロー ルはレシチン 2 分子膜に大量に溶け, 逆へキサゴナル構 造などの逆トポロジー構造を形成する。これ等の中性脂 質は生体膜で情報を伝達に関与すると考えられている. 
2 分子膜中のジグリセライドは種々の phospholipase を 活性化する.

d. これらの脂質分子は膜，リポ蛋白間で動的平衡状 態にあり, その動きを支配するのは物理化学ポテンシャ ルである.

\section{文献}

1) T. Handa and M. Nakagaki : Adv. Collid Interface Sci., 38, 45 (1992). 半田哲郎 : 薬学雑誌, 111, 410 (1991)

2) J.C.L. Mamo, A. Bowler, C.L. Elsegood and T.G. Redgrave : Biochim. Biophys. Acta, 1081, 241 (1991)

3) S. Das and R.P. Rand : Biochemistry, 25, 2882 (1986)

4) I. Yamamoto, T. Mazumi, T. Handa and K. Miyajima : Biochim. Biophys. Acta, 1145, 293 (1993)

5) H. Gutman, G. Arvidson, K. Fontell and G. Lindblom : "Surfactant in Solution" (K. Mittal and B. Lindman, eds.) Vol. 1, p. 143, Planum Press, New York (1984)

6) P. K. Hansrain, S. S. Davis, M. J. Groves : J. Parent. Sci. Tech., 37, 145 (1983), M. Badr, D. R. Kodali and T. G. Redgrave : J. Colloid In- terface Sci., 113, 414 (1986)

7) A. R. Tall D. M. Small : Adv. Lipid Res, 17, 1 (1980)

8) T. Handa, H. Saito and K. Miyajima : Biochemistry, 29, 2884 (1990)

9) T. Handa, H. Saito, I. Tanaka, A. Kakee, T. Tanaka, and K. Miyajima : Biochemistry, 31, 1415 (1992)

10) 半田哲郎，江口裕子，宮嶋孝一郎：第 34 回日本脂 質生化学研究集会要旨 p. 199 (1992), 投稿中

11) C-C. Yin, P. Schurtenberger, E. Wehrili, F. Paltauf and H. Hauser : Biochim. Biophys. Acta. 1070, 33 (1991)

12) F. Bellemare and M. Fragata : J. Membrane Biol., 58, 67 (1981)

13) T. Handa, Y. Asai, K. Miyajima, Y. Kawashima, M. Kayano, K. Ida and T. Ikeuchi : $J$. Colloid Interface Sci., 143, 205 (1991)

14) T. Yuzuriha, M. Takano and K. Katayama : Biochim. Biophys. Acta, 759, 286 (1983), M. Takada, T.Yuzuriha, K.Katayama, C. Yamato. and N. Katayama : J. Nutr. Sci. Vitaminol., 31, 115 (1985)

15) T.Handa, Y.Asahi, H.Komatsu, and K.Miyajima : J. Colloid Interface Sci., 153, 303 (1992) (受付 1992 年 12 月 10 日)

\section{'93 新素材展（第 9 回）}

〔機能材料・部品，新用途，加工成形技術の

$$
\mathrm{R} \& \mathrm{D} \text { マーケティングショー] }
$$

会 期：1993年 5 月 18 日（火） 21 日（金） 4 日間

午前 10 時〜午後 5 時（最終日 午後 4 時終了）

会 場 : 日本コンベンションセンター・幕張メッセ

（千葉県千葉市美浜区中瀬 2-1）

会場面積 : $27,000 \mathrm{~m}^{2}$

展示小間 : 1,200 小間予定 (1 小間 $9.0 \mathrm{~m}^{2}$ )

入場料：1,000 円・団体料金（20名以上） 700 円

対 象 : 官公庁, 企業の商品開発・設計, 材料製品化戦略の意志決定者（経営者・幹部, 経営企

画部門，購買・資材部門，生産・製造部門，技術・研究・開発部門など）

主 催 : 日本経済新聞社

材料連合フォーラム（会長 斉藤進六東京工業大学名誉教授）

後援(予定) : 通商産業省, 外務省, 文部省, 科学技術庁, 工業技術院, 日本商工会議所, 経済団

体連合会, 日本貿易振興会（順不同）

協力 (予定)：日経 BP 社，テレビ東京

協賛 $($ 予定 $):$ 日本膜学会ほか 